\title{
TITLE:
}

\section{Review on utilization and composition of coffee silverskin}

$\operatorname{AUTHOR}(\mathrm{S})$ :

Narita, Yusaku; Inouye, Kuniyo

\section{CITATION:}

Narita, Yusaku ...[et al]. Review on utilization and composition of coffee silverskin. Food Research International 2014, 61: 16-22

ISSUE DATE:

2014-07

URL:

http://hdl.handle.net/2433/188926

\section{RIGHT:}

(c) 2014 Elsevier Ltd.; この論文は出版社版でありません。引用の際には 出版社版をご確認ご利用ください。; This is not the published version. Please cite only the published version. 
1 TITLE:

2 Review on utilization and composition of coffee silverskin

3 AUTHORS :

4 Yusaku Narita* and Kuniyo Inouye ${ }^{*}, \dagger$

5

6 AFFILIATION AND ADDRESS:

$7 \quad{ }^{\dagger}$ Division of Food Science and Biotechnology, Graduate School

8 of Agriculture, Kyoto University, Sakyo-ku, Kyoto 606-8502,

9 Japan ${ }^{\ddagger}$ R\&D Center, UCC Ueshima Coffee Co., Ltd., 3-1-4 Zushi,

10 Takatsuki-shi, Osaka 569-0036, Japan

11

12 AUTHOR EMAIL ADDRESS:

13 inouye@kais.kais.kyoto-u.ac.jp

14 yuusaku-narita@ucc.co.jp

15

16

17 CORRESPONDING AUTHOR FOOTNOTE:

18 * To whom correspondence should be addressed. Tel:

$19+81-75-753-6266, F a x:+81-75-753-6265$, Email: inouye@kais.

20 kyoto-u.ac.jp

21

22

23 


\section{$24 \quad$ Abstract}

25

26 Coffee is one of the most frequently consumed drinks in the 27 world. Coffee silverskin (CS) is the only by-product produced 28 during the coffee beans roasting process, and large amounts of 29 CS are produced by roasters in coffee-consuming countries. 30 However, methods for the effective utilization of CS have not 31 been developed. Reuse of CS, which is the primary residue from 32 the coffee industry, is important for the environment and 33 economy. Recently, there have been some attempts to reuse CS 34 for biological materials and as a nutrient source for solid-state 35 fermentation. The purpose of this review is to provide an 36 overview about CS, its chemical composition, biological activity, 37 and attempts at its reuse.

42 Keywords: Coffee; Coffee silverskin; By-product; Composition; 43 Review. 
46 List of abbreviations

47
$48 \quad \mathrm{CS}$
Coffee silverskin
49 CGAs
Chlorogenic acids
$505-\mathrm{CQA}$
5-Caffeoylquinic acid
$515-\mathrm{HMF}$
5 - (Hydroxymethyl)- 2 -furfural 


\section{Introduction}

\subsection{Coffee}

Coffee is one of the most frequently consumed drinks in the world. Approximately 7 million tons of green coffee beans were produced globally in 2010 (Food and Agricultural Organization). With the increase in the number of coffee consumers in both importing and exporting countries, annual coffee production has increased. Coffee is grown primarily in the area between the $25^{\circ} \mathrm{N}$ latitude and the $25^{\circ} \mathrm{S}$ latitude, known as "the coffee belt". More than 60 countries produce green coffee beans (Lashermes,

63 Andrade, \& Etienne, 2008; Vieira, 2008). Brazil is the global 64 leader in production of green coffee beans, followed by Vietnam, 65 Indonesia, Colombia, and India (United States Department of 66 Agriculture; Bacon, 2005 ).

Coffee plants belong to the botanical family Rubiaceae, 68 which includes approximately 80 species. Two major coffee species are cultivated for drinking. Coffea arabica, known as arabica coffee, accounts for approximately $75 \%$ of global coffee

71 production and $C$. canephora, known as robusta coffee, accounts 72 for approximately $24 \%$ of global coffee production (van Boxtel, 73 Berthouly, Carasco, Dufour, \& Eskes, 1995; Casal, Oliveira, 74 Alves, \& Ferreira, 2000 ; Bertrand, Ramirez, Topart, \& Anthony, 75 2002). Coffee beans are roasted using dry heat at temperatures between $200^{\circ} \mathrm{C}$ and $300^{\circ} \mathrm{C}$ with constant agitation to ensure even 77 heating. During roasting, the color of green coffee beans shifts 78 to yellow, then to a suntan-like light brown, and later to a dark, oily brown color. Some of the natural sugars in the beans are 
80 transformed into $\mathrm{CO}_{2}$ gas, and others are caramelized into the

81 complex flavor essences that contribute to good taste and color.

82 Chlorogenic acid lactones produced from chlorogenic acids

83 (CGAs) by roasting green coffee beans has contributed to the 84 bitter taste of brewed coffee (Farah, de Pulis, Trugo, \& Martin, 85 2005; Farah, de Paulis, Moreira, Trugo, \& Martin, 2006). In recent years, in addition to studies of taste and flavor, attention has been focused on the biological activities of coffee ingredient. In particular, it has been reported that CGAs have various bioactivities, such as antioxidant activity (Iwai, Kishimoto, Kakino, Mochida, \& Fujita, 2004), $\alpha$-amylase inhibition (Narita \& Inouye, 2009, 2011), lipase inhibition (Narita, Iwai, Fukunaga, \& Nakagiri, 2012), antihyperglycemic effects (Iwai et al. 2012),

\subsection{Coffee silverskin}

Figure 1 shows the structure of the fruit (coffee cherry) of the coffee tree (Saenger, Hartge, Werther, Ogada, \& Siagi, 2001). The coffee cherry is oval and approximately $10 \mathrm{~mm}$ in size. Green coffee beans exist inward in the coffee cherry and are covered by a thin seed skin known as coffee silverskin (CS), an

101 endocarp called the parchment, a pectic adhesive layer, pulp, and epicarp (outer skin) in the order (Saenger, Hartge, Werther,

103 Ogada, \& Siagi, 2001). Green coffee beans are generally 104 produced via two processes, purification and thresh process 105 (Casal et al., 2004; Bytof, Knopp, Schieberle, Teutsch, \& Selmar, 106 2005; Knopp, Bytof, \& Selmer, 2006; Bytof et al., 2007). For the 107 purification process, two methods generally are used. One is the 
108 "washed" or "wet" method and the other is "unwashed", 109 "natural" or "dry" method. In general, more CS is obtained from 110 green coffee beans purified by the dry method than from those 111 purified by the wet method. The outer skin, pulp, pectic adhesive 112 layer, and parchment are completely removed from the green 113 coffee beans in these two processes. However, a portion of CS 114 remains with the green coffee beans after their treatment. The 115 green coffee beans with attached CS are exported to consuming 116 countries from producing countries, and the beans are roasted by 117 suppliers in the consuming countries. Thus, CS is the only 118 by-product produced in the roasting process, and large amounts 119 of CS are produced by large-scale coffee roasters in consuming 120 countries.

121 Many research groups are focusing on the utilization of coffee 122 wastes that are by-products of the coffee brewing process as 123 source of sugars, minerals and fibers; as alternative renewable 124 energy sources (bio-diesel oil and bio-ethanol); and as electrode 125 materials (Mussatto, Carneiro, Silva, Roberto, \& Teixeira, 2011; 126 Al-Hamamre, Foerster, Hartmann, Kroger, \& Kaltschmitt, 2012; 127 Kondamudi, Mohapatra, \& Misra, 2008; Rufford, 128 Hulicova-Jurcakova, Zhu, \& Lu, 2008). Studies on the utilization 129 of coffee waste have advanced worldwide (Mussatto, Machado, 130 Martins \& Teixeira, 2011; Esquivel \& Jimenez, 2012; Murthy \& 131 Madhava Naidu, 2012), but methods for the effective utilization 132 of CS have not been developed. Thus, most CS is disposed of as 133 industrial waste. CS is the only by-product of the coffee bean 134 roasting process, and CS can only be collected in large amounts 135 from roasting factories. Therefore, CS is a resource that may be 
136 easy to reuse, and it can be regarded as biomass that is expected 137 to be utilized in the future.

\section{Chemical composition of CS}

\subsection{Dietary fiber in CS}

CS ingredients and the amounts thus far reported are 144 summarized into Table 1. Dietary fiber is important for nutrition 145 and health and is used as a therapeutic material for physiological 146 problem such as diabetes and hyperlipidemia (Saura-Calixto, 147 Garcia-Alonso, Goni, \& Bravo, 2000). It is thought that dietary 148 fiber will help in preventing cardiovascular disorders by 149 arteriosclerosis or the serious complications of diabetes, because 150 this controls the absorption of cholesterol and fat into the body 151 by adsorbing them. CS has a high dietary fiber (50-60\%), which 152 includes $15 \%$ soluble dietary fiber and $85 \%$ insoluble dietary 153 fiber (Borrelli, Esposito, Napolitano, Ritieni, \& Fogliano, 2004; 154 Napolitano et al., 2006; Pourfarzad, Mahdavian-Mehr, \& 155 Sedaghat, 2013; Napolitano, Fogliano, Tafuri, \& Ritieni, 2007). 156 Napolitano et al. (2007) investigated CS dietary fiber obtained 157 from four types of $C$. arabica samples from Ethiopia, Santos, 158 India, and Costa Rica, and three types of C. canephora samples 159 from Ivory Coast, Vietnam, and Cameroon. They reported that 160 there were no significant differences in the dietary fiber and 161 soluble dietary fiber contents between all samples tested. The 162 dietary fiber content of CS is higher than that of dietary plant 163 foods such as apple (28.43\%), Broccoli (28.94\%), cabbage 
$164(22.41 \%)$, carrot $(28.4 \%)$, wheat bran $(41.97 \%)$, oat bran $165(28.60 \%)$, and potato (2.85\%) (Southgate, 1978; Anderson \& 166 Bridges, 1988; Chen, Rubenthaler, Leung, \& Baranowski, 1988). 167 It has been reported that insoluble dietary fiber shortens 168 intestinal transit, thereby allowing less time for carbohydrates to 169 be absorbed (Montonen, Knekt, Jarvinen, Aromaa, \& Reunanen, 170 2003). Insoluble dietary fiber is considered effective for 171 prevention and remedial treatment of diabetes by controlling the 172 carbohydrate absorption time (Hayashi et al., 2010; van de Laar 173 et al., 2005). Therefore, CS consumption may be effective for the 174 prevention and treatment of diabetes. However, this is the 175 possibility suggested from the results obtained from an in vitro 176 experiment, and in vivo experiment is necessary in order to 177 confirm the presence or absence of the effects. Before that, it is 178 necessary to confirm that there is no toxicity from intake of CS 179 for humans. Recently, Lang et al. reported that

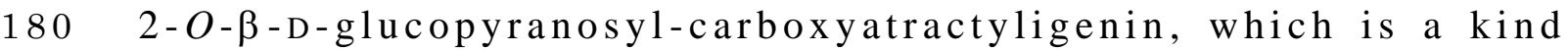
181 of aminoglycoside and inhibits ATP-production in isolated 182 mitochondria by blockage of adenine nucleotide translocase, was 183 found in raw coffee bean (Lang, Fromme, Beusch, Wahi, 184 Klingenspor, \& Hofmann, 2013).

185 In general, plant dietary fiber consists of hemicelluloses, 186 cellulose, lignin, oligosaccharides, polysaccharides, pectins, 187 gums, and waxes (Lecumberri et al., 2007; Harris \& Smith, 2006; 188 Rodriguez, Jimenez, Bolanos, Guillen, \& Heredia, 2006). It is 189 reported that $34.6-80.5 \%$ of carbohydrates are included in CS 190 (Borrelli et al., 2004; Napolitano et al., 2006; Pourfarzad et al., 191 2013; Napolitano et al., 2007). CS contains approximately $30 \%$ 
192 lignin, and the polysaccharides in CS are $17.8 \%$ glucan, $4.7 \%$ 193 xylan, 2\% arabinan, 3.8\% galactan, and 2.6\% mannan (Mussatto, 194 Machado, Carneiro, \& Teixeira, 2012). It is suggested that CS 195 has little monosaccharide contents because the contents of 196 reducing sugars was low (Borrelli et al., 2004; Napolitano et al., $1972006)$.

198

\subsection{Protein, fat, and ash in CS}

200 CS contains protein, fat, and ash, at 16.2-19.0\%, 1.56-3.28\%, 201 and 7\%, respectively (Borrelli et al., 2004; Napolitano et al., 202 2006; Pourfarzad et al., 2013; Napolitano et al., 2007). The total 203 mineral contents of green coffee beans are approximately $4 \%$ 204 (w/w dry matter) (Grembecka, Malinowska, \& Szefer, 2007; 205 Clarke \& Walker, 1974). It is reported that mineral contents of 206 roasted coffee beans are 4-5\% (Franca, Oliveira, Mendonca, \& 207 Silva, 2005; Tawfik \& El Bader, 2005; Oliveira, Franca, 208 Mendonca, \& Barros-Junior, 2006). The main component of 209 mineral in green coffee beans is potassium, and its contents are 210 approximately $40 \%$ of the amounts of total mineral (Clarke \& 211 Walker, 1974). The compositions of minerals CS have not been 212 clarified so far. De Assuncao et al. (2012) reported that the 213 contents of calcium are higher than potassium in coffee husk. CS 214 has approximately 0.81-1.37\% caffeine (Napolitano et al., 2007). 215 Coffee beans contain $1-3 \%$ (w/w dry matter) caffeine 216 (Alonso-Salces, Serra, Reniero, \& Heberger, 2009; Belay, 2011; 217 Ky et al., 2001). Thus, the caffeine contents of CS are lower than 218 that of coffee beans. Napolitano et al. (2007) investigated seven 219 types of CS from different growing areas and species that differ 
220 in their protein, fat, carbohydrate, reducing sugar, caffeine, total 221 dietary fiber, insoluble dietary fiber, and soluble dietary fiber 222 contents. They showed that there were no significant correlations 223 between geographic variety and growth conditions in which CS 224 was produced and the chemical composition of CS.

\subsection{Summary of chapter 2}

227 This brief overview describes the CS constituents, and in 228 particular, those that may promote health. There is a possibility 229 that it can be used as a source of dietary fiber and minerals as CS 230 has high contents of these. CS is the major by-product of the 231 roasting process, and easily peels off from roasted coffee beans 232 in the roasting process of green coffee beans. Therefore, it is 233 considered that the amounts of CS ingredients vary with the 234 degree of roasting, because the ingredient contents of roasted 235 coffee beans varies with the degree of roasting (Farah, et al., 236 2005; Somporn, Kamtuo, Theerakulpisut, \& Siriamornpun, 2011). 237 We expect to learn more in the future about CS constituents, such 238 as flavor, pigments, and organic acids, and the variety of CS 239 ingredient that differ according to the degree of roasting and the 240 species of green coffee beans.

241 In the case of using CS to liquid processed products such as 242 beverages and detergents, CS water extracts are more convenient 243 than CS of solid matter. For example, CS has high amounts of 244 dietary fiber of about 50-60 g/100 g (Table 1). However, when 245 the amounts of soluble and insoluble fractions of the dietary 246 fiber in CS are compared, the former is about $1 / 10$ of the latter 247 (Table 1). Then, we summarized CS water extracts in next 
248 subject.

\section{CS water extracts}

\subsection{Yields of soluble solid from CS}

253 It has been reported that yields of soluble solid obtained from 254 CS by water extraction change with the extraction temperature 255 (Furusawa, Narita, Iwai, Fukunaga, \& Nakagiri, 2011; Narita \& 256 Inouye, 2012). The yields with extraction at $25^{\circ} \mathrm{C}$ and $80^{\circ} \mathrm{C}$ were $25716 \%$ (w/w dry matter) and $19 \%$ (w/w dry matter), respectively 258 (Furusawa et al., 2011; Narita \& Inouye, 2012). Furusawa et al. 259 (2011) reported that the amounts of total sugars in CS water 260 extracts were $29.5 \%$ (w/w dry matter) and that the extracts 261 contained acidic polysaccharides. It has been suggested that 262 these polysaccharides are pectic substances because they have a 263 high uronic acid content (Furusawa et al. 2011).

264 Water maintained in the liquid state with pressure at 265 temperatures ranging between $100^{\circ} \mathrm{C}$ and $374{ }^{\circ} \mathrm{C}$ is called 266 subcritical water. The specific inductive capacity or dielectric 267 constant of water decreases remarkably with increasing 268 temperature (Miller \& Hawthorne, 1998). Moreover, subcritical 269 water functions as an acid or alkali catalyst because the ionic 270 product of subcritical water is higher than water under normal 271 temperature and pressure conditions. Recently, Subcritical water 272 has been used extensively for research on extracting ingredients 273 from food waste such as okara (Wakita et al., 2004), wheat bran 274 (Kataoka, Wiboonsirikul, Kimura, \& Adachi, 2008), and defatted 275 rice bran (Wiboonsirikul et al., 2007). The yields of CS extracts 
276 from water treatment increased with extraction temperature from $27725^{\circ} \mathrm{C}$ to $210^{\circ} \mathrm{C}$ and decreased in a temperature-dependent manner 278 in the temperature range of $210-270^{\circ} \mathrm{C}$ (Table 2). The highest 279 yields (29\%, w/w dry matter) of CS extracts by water treatment 280 were obtained at an extraction temperature of $210^{\circ} \mathrm{C}$ and were 281 1.8-fold higher than that obtained at $25^{\circ} \mathrm{C}$ (Narita \& Inouye, 282 2012). We summarized in Table 2 about the chemical composition 283 such as proteins, carbohydrates, caffeine, and total phenolics of 284 the CS water extracts. Table 2 shows that their chemical 285 composition of CS water extracts changes by difference of 286 extraction temperature.

\subsection{Yields of proteins, carbohydrates, caffeine, and total} phenolics from CS

We converted the yields of proteins, carbohydrates, caffeine, and total phenolics obtained from CS of solid by water extraction using the amounts of each component of CS water extracts and the yields of soluble solids (Table 3 ). The amounts of protein extracted from CS by the water treatment at $25-80^{\circ} \mathrm{C}$ are about $20 \%$ of the protein contents in the CS of solid from values in Tables 1 and 3 . It is roughly estimated that the proteins nearly $80 \%$ was insoluble from this result. The amounts of protein of approximately $80 \%$ in CS of solid were extracted by subcritical water treatment at $240^{\circ} \mathrm{C}$. These results indicate that part of the insoluble proteins in CS of solid was hydrolyzed and solubilized.

301 The soluble proteins produced by subcritical water treatment 302 from CS may be used as nutrients or food additives in food, 303 drinks and supplements for human. However, composition of the 
304 proteins extracted from CS by subcritical water treatment has not 305 been reported until now. As undermentioned, it has been reported 306 that CS water extracts have antioxidant activities (Narita \& 307 Inouye, 2012). It is reported that proteins produced by 308 subcritical water treatment from deoiled rice bran, which is an 309 agro-industrial residue of the rice milling process, showed high 310 antioxidant activity and were proven to be useful for application 311 as a culture medium for yeast growth (Sereewatthanawut, 312 Prapintip, Watchiraruji, Goto, Sasaki, \& Shotipruk, 2008). It is 313 reported that the peptides produced by the decomposition of 314 soybean protein and wheat gluten have high antioxidant activity 315 (Park, Morimae, Matsumura, Nakamura, \& Sato, 2008). Proteins 316 or peptides produced by subcritical water treatment from CS 317 might have antioxidant activity. The yields of caffeine from CS 318 were almost constant at $0.4 \%$ (w/w dry matter) at extraction 319 temperatures in the range of $25-270^{\circ} \mathrm{C}$ (Narita \& Inouye, 2012). 320 Total phenolic contents of the CS extracts obtained by water 321 treatment increased with increasing extraction temperature from $32225^{\circ} \mathrm{C}$ to $240^{\circ} \mathrm{C}$ (Narita \& Inouye, 2012). Subcritical water 323 treatment was effective for the extraction of phenolic 324 components (Narita \& Inouye, 2012). 5-Caffeoylquinic acid 325 (5-CQA) was extracted at $0.1-0.2 \%(\mathrm{w} / \mathrm{w}$ dry matter) from CS in 326 the temperature range of $25-180^{\circ} \mathrm{C}$, but It was not extracted in 327 the temperature range of $210-270^{\circ} \mathrm{C}$ (Narita \& Inouye, 2012). It 328 was considered that 5-CQA in CS was not detected with heat 329 treatment because it was reported that 5-CQA decreased with 330 increasing temperature (de Maria, Trugo, de Mariz e Miranda, \& 331 Salvador, 1998) and under alkaline conditions (Narita \& Inouye, 
332

333

2013). Bresciani et al. reported that CS extract, which is prepared using acidified water ( $1 \%$ aqueous formic acid) at $70^{\circ} \mathrm{C}$ for $1 \mathrm{~h}$, are included 3-CQA, 4-CQA, 5-CQA, 4-feruloylquinic acid (4-FQA), 5-FQA, 3-coumaroylquinic acid (3-CoA), and 5-CoA (Bresciani, Calani, Bruni, Brighenti, \& Del Rio, 2013). The content of 3-CQA, 4-CQA, 5-CQA, total of 4-FQA and 5-FQA, 3-CoA, and 5-CoA are $147.8 \mathrm{mg} / 100 \mathrm{~g}, 84.9 \mathrm{mg} / 100 \mathrm{~g}$, $198.9 \mathrm{mg} / 100 \mathrm{~g}, 121.6 \mathrm{mg} / 100 \mathrm{~g}, 2.4 \mathrm{mg} / 100 \mathrm{~g}$, and $5.7 \mathrm{mg} / 100 \mathrm{~g}$, respectively (Bresciani, et al., 2013).

The amounts of 5-(hydroxymethyl)-2-furfural (5-HMF) extracted from CS were increased with subcritical water treatment (Narita \& Inouye, 2012). 5-HMF is considered a main degradation product formed by dehydration of hexoses through hydrothermolysis (Khajavi, Kimura, Oomori, Matsuno, \& Adachi, 2005 ; Usuki, Kimura, \& Adachi, 2008).

\subsection{Summary of chapter 3}

This brief overview of CS extracts sheds light on the extraction of active ingredients from CS. In particular, it is considered that subcritical water treatment is effective for the extraction of active ingredients such as proteins and phenolic components. The extraction of active ingredients from CS using subcritical water without organic solvents and other catalysts is expected to be environment friendly. We expect more investigational advances in the future on the composition of CS and effective methods for extraction of active ingredients from CS .

About utilization of CS, two usages are suggested. One is the 
360 use as bioactive substance, and another is solid-state 361 fermentation using CS. We summarized it in a following subject 362 about the study on these usages.

363

\section{Bioactivity of CS}

365

\subsection{Antioxidant effect of CS}

Antioxidants exert important effects for human health by reducing oxidative stress because the stress is a factor in the 369 development of various diseases such as cancer (Lambert \& Yang, 370 2003), cardiovascular disease (Diaz, Frei, Vita, \& Keaney, 1997), 371 type 2 diabetes (Takayanagi, Inoguchi, \& Ohnaka, 2011), 372 alzheimer's disease (Christen, 2000), and Parkinson's disease 373 (Lang \& Lozano, 1998). Borrelli et al. (2004) reported that CS 374 methanol extracts have an antioxidant activity evaluated with 375 ABTS [(2,2'-azobis(3-ethylbenzothiazoline-6-sulfonic acid)) 376 radical scavenging ability similar to that of wheat bran, which is 377 known to have very high antioxidant activity (Andlauer \& Furst, 378 1998). It was reported that CS extracts obtained by water 379 treatment at several temperatures also have antioxidant activity 380 (Narita \& Inouye, 2012). The antioxidant activity of CS water 381 extracts were evaluated using H-ORAC assay and DPPH assay 382 (Narita \& Inouye, 2012). The H-ORAC and DPPH values of CS 383 extracts obtained after water treatment at $25-270^{\circ} \mathrm{C}$ increased 384 remarkably with increasing extraction temperatures (Table 2). 385 The highest H-ORAC and DPPH values of CS extracts were 386 observed at $270{ }^{\circ} \mathrm{C}$, and were $379 \mu \mathrm{mol} \mathrm{TE} / \mathrm{g}$ of CS extract and $3872629 \mu \mathrm{mol} \mathrm{TE} / \mathrm{g}$ of CS extract, respectively (Table 2). In regard 
388 to the factors H-ORAC values of CS extracts has increased 389 remarkably with increasing extraction temperatures, Narita \& 390 Inouye (2012) have mentioned two possibilities. One is the 391 possibility of the phenolic components that the CS water extracts 392 may contribute, another is the possibility that peptides produced 393 by hydrolysing the proteins in CS by subcritical water treatment 394 in the temperature range of $180-270^{\circ} \mathrm{C}$ have a high antioxidant 395 activity (Narita \& Inouye, 2012). It is reported that the peptides 396 produced by the decomposition of soybean protein and wheat 397 gluten have high antioxidant activity (Park, Morimae, Matsumura, 398 Nakamura, \& Sato, 2008). H-ORAC values of fruits such as 399 blueberry, plum, raspberry, apple, and orange, and vegetables 400 such as carrot, green pepper, and spinach are in the range of 5-70 $401 \mu$ mol TE/g (Wu, Beecher, Holden, Haytowitz, Gebhardt, \& Prior, 402 2004). Even the H-ORAC value (354 $\mu \mathrm{mol} \mathrm{TE} / \mathrm{g}$ of CS extracts) 403 of CS extracts by treatment water at $25^{\circ} \mathrm{C}$ showed that it was 404 higher than that of the above mentioned fruits and vegetables. 405 However, this is the possibility suggested from the results 406 obtained from an in vitro experiment, and in vivo experiment is 407 necessary in order to confirm the presence or absence of the 408 effects. A study to confirm an antioxidant effect of CS will be 409 necessary in vivo experiment in future. Furthermore, 410 Identification of ingredients contributing to the antioxidant 411 effect of CS is necessary in in vitro experiments.

412

413 4.2. Prebiotic effect and inhibitory activity on hyaluronidase 414 by $\mathbf{C S}$

415 It has been reported that CS has prebiotic properties and 
416 supports the growth of bifidobacteria (Borrelli et al., 2004).

417 However, CS has also found proliferative activity of coliforms

418 weaker than the increase effect of bifidobacteria (Borrelli et al.,

419 2004). These results are evaluated after $24 \mathrm{~h}$ of fermentation. It 420 seems that a detailed study on growth time and species of 421 bacteria is more necessary. Hyaluronidase inhibitors appear to be 422 effective in suppressing allergies and inflammations (Kakegawa, 423 Matsumoto, \& Satoh, 1992). Furusawa et al. (2011) reported that 424 the inhibitory effects of CS extracts against hyalurodidase are 425 similar to those of disodium cromoglycate, which is a potent 426 antiallergen.

\subsection{Summary of chapter 4}

429 As noted above, Antioxidant, prebiotic substance, and 430 hyaluronidase inhibitor are considered as a utilization method of 431 the CS as a bioactive substance. In particular, there is a 432 possibility that CS could be used as a good source of 433 antioxidants. However, there are very few reports about the 434 bioactivity of CS. Moreover, the contributions of CS ingredients 435 to the physiological functions of CS have not been reported, and 436 it appears that further future research is required.

5. Solid-state fermentation using CS

440 Solid-state fermentation is one of the effective methods for 441 producing or extracting useful ingredients from food and 442 agricultural waste products (Gombert, Pinto, Castilho, \& Freire, 443 1999; Rodriguez Couto \& Sanroman, 2005, 2006). Food waste 
444 used as biomass is easy to corrupt because microbe growth tends 445 to increase in it. Therefore, food waste can change to materials 446 with various functions by suitable fermentation processing for 447 promoting propagation of microbes. Murthy, Naidu, and Srinivas 448 (2009) reported that $\alpha$-amylase production by Neurospora crassa 449 CFR 308 with CS as a substrate is possible under solid-state 450 fermentation conditions. Fructooligosaccharides (FOS) are 451 produced commercially via enzymatic synthesis from sucrose by $452 \beta$-fructofuranosidase (EC.3.2.1.26) or fructosyltransferase 453 (EC.2.4.1.9) from fungi such as Aspergillus, Aureobasidum, and 454 Penicillium (Balasubramaniem, Nagarajan, \& Paramasamy, 2001 ; 455 Chien, Lee, \& Lin, 2001; Mussatto \& Teixeira, 2010). Mussatto 456 and Teixeirra (2010) reported that high production of 457 fructooligosaccharides by A. japonicus under solid-state 458 fermentation was obtained when CS was used as a nutrient source. 459 Machado, Rodriguez-Jasso, Teixeira, and Mussatto (2012) 460 reported that seven fungal strains, including $A$. ustus PSS, $A$. 461 niger AA20, A. niger GH1, A. niger PSH, Mucor Sp. 3P, N. 462 crassa ATCC10337, and Penicillium purpurogenum GH2 could 463 grow on CS under solid-state conditions. Moreover, $P$. 464 purpurogenum GH2, N. crassa ATCC10337, and Mucor Sp. 3P 465 were able to release phenolic compounds from CS (Machado, 466 Rodriguez-Jasso, Teixeira, \& Mussatto, 2012). CS is transformed 467 into value-added products by fermentation under solid-state 468 conditions using various fungi.

469 SSF is very useful as effective use of industrial waste and 470 excels in environmental, economic, and safety aspect, because it 471 requires only minimum quantity of water. Therefore, a seemingly 
472 effective utilization method of CS is to use it as a substrate of 473 SSF. FOS is producible by A. japonicus under SSF when CS was 474 used as a nutrient source (Mussatto \& Teixeira, 2010), and has 475 been shown to beneficially modulate the composition of 476 intestinal bacterial flora and notably to increase bifidobacteria 477 and lactobacilli in vivo (Orrhage, Sjostedt, \& Nord, 2000). As 478 mentioned above, it has been reported that CS has prebiotic 479 properties and supports the growth of bifidobacteria (Borrelli et 480 al., 2004). However, the active ingredients in CS are not clear 481 for both production of FOS by SSF with CS and A. japonicus and 482 for prebiotic effects of CS. Identification of these active 483 ingredients of CS is necessary in the future.

\section{Conclusion}

Coffee is one of the most frequently consumed drinks in the world. CS is the only by-product produced in the coffee bean roasting process, and large amounts of CS are produced by roasters in consuming countries. Therefore, establishment of effective use of CS is important. Two suggestions are shown for a direction of the utilization of CS. One is the use of CS as a

493 bioactive substance or the source thereof. It is reported that CS 494 has hyaluronidase inhibition, prebiotic properties, and 495 antioxidant activity. Another is the use of CS as a substrate of SSF. It is necessary to identify the active substance in CS against 497 the above-mentioned effects, bioactive activity in particular, in 498 the future. Feasibility will be high if these effects are proved by 499 subsequent experiments such as a large-scale experiment for 
500 industrialization and a clinical trial in the future, because there 501 are economic benefits in order that these uses help decrease the 502 cost of disposal of CS.

503 In order to achieve high utilization of CS as biomass resources, 504 active substances are collected gradually, and the construction of 505 the systematized development system that can finally use it for 506 feed, fertilizer, microbial fermentation materials for biorefinery, 507 and recovery of the energy by combustion is important. In the 508 future, further study on the components of CS and their 509 functionality is not only required, but construction of databases 510 that can share their information is also important. 


\section{References}

512

513 Al-Hamamre, Z., Foerster, S., Hartmann, F., Kroger, M., \& 514 Kaltschmitt, M. (2012). Oil extracted from spent coffee grounds 515 as a renewable source for fatty acid methyl ester manufacturing. 516 Fuel, 96, 70-76.

517 Alonso-Salces, R. M., Serra, F., Reniero, F., \& Heberger, K. 518 (2009). Botanical and geographical characterization of green 519 coffee (Coffea arabica and Coffea canephora): chemometric 520 evaluation of phenolic and methylxanthine contents. Journal of 521 Agricultural and Food Chemistry, 57, 4224-4235.

522 Anderson, J. W., \& Bridges, S. R. (1988). Dietary fiber content 523 of selected foods. The American Journal of Clinical Nutrition. $524 \quad 47,440-447$.

525 Andlauer, W., \& Furst, P. (1998). Antioxidative power of 526 phytochemicals with special reference to cereals. Cereal Food 527 World, 43, 356-360.

528 Bacon, C. (2005). Confronting the coffee crisis: can fair trade, 529 organic, and specialty coffees reduce small-scale farmer 530 vulnerability in Northern Nicaragua? World Development, 33 , $531 \quad 497-511$.

532 Balasubramaniem, A. K., Nagarajan, K. V., \& Paramasamy, G. 533 (2001). Optimization of media for $\beta$-fructofuranosidase 534 production by Aspergillus niger in submerged and solid state 535 fermentation. Process Biochemistry, 36, 1241-1247.

536 Belay, A. (2011). Some biochemical compounds in coffee beans 537 and methods developed for their analysis. International Journal 538 of the Physical Sciences, 6, 6373-6378. 
539 Bertrand, B., Ramirez, G., Topart, P., \& Anthony, F. (2002).

540 Resistance of cultivated coffee (Coffea Arabica and C.

541 canephora) trees to corky-root by Meloidogyne arabicida and

542 Fusarium oxysporum, under controlled and field conditions. Crop

543 Protection, 21, 713-719.

544 Borrelli, R. C., Esposito, F., Napolitano, A., Ritieni, A., \&

545 Fogliano, V. (2004). Characterization of a new potential

546 functional ingredient: coffee silverskin. Journal of Agricultural

547 and Food Chemistry, 52,1338-1343.

548 Bresciani, L., Calani, L., Bruni, R., Brighenti, F., \& Del Rio, D.

549 (2013). Phenolic composition, caffeine content and antioxidant

550 capacity of coffee silverskin. Food Research International, in

551 press, DOI: $10.1016 /$ j.foodres.2013.10.047.

552 Bytof, G., Knopp, S.-E., Schieberle, P., Teutsch, I., \& Selmar, D.

553 (2005). Influence of processing on the generation of $554 \gamma$-aminobutyric acid in green coffee beans. European Food 555 Research and Technology, 220,245-250.

556 Bytof, G., Knopp, S.-E., Kramer, D., Breitenstein, B., Bergervoet, 557 J. H. W., Groot, S. P. C., \& Selmar, D. (2007). Transient 558 occurrence of seed germination processes during coffee 559 post-harvest treatment. Annals of Botany, 100, 61-66.

560 Casal, S., Oliveira, M. B. P. P., Alves, M. R., \& Ferreira, M. A. 561 (2000). Discriminate analysis of roasted coffee varieties for 562 trigonelline, nicotinic acid, and caffeine content. Journal of 563 Agricultural and Food Chemistry, 48, 3420-3424.

564 Casal, S., Mendes, E., Alves, M. R., Alves, R. C., Beatriz, M., 565 Oliveira, P. P., \& Ferreira, M. A. (2004). Free and conjugated 566 biogenic amines in green and roasted coffee beans. Journal of 
Agricultural and Food Chemistry, 52, 6188-6192.

Chien, C.-S., Lee, W.-C., \& Lin, T.-J. (2001). Immobilization of Aspergillus japonicus by entrapping cells in gluten for production of fructooligosaccharides. Enzyme and Microbial Technology, 29, 252-257.

Chen, H., Rubenthaler, G. L., Leung, H. K., \& Baranowski, J. D. (1988). Chemical, physical, and baking properties of apple fiber compared with wheat and oat bran. Cereal Chemistry, 65, 244-247.

576 Christen, Y. (2000). Oxidative stress and Alzheimer disease. The American Journal of Clinical Nutrition, 71, 621S-629S.

578 Clarke, R. J., \& Walker, L. J. (1974). Potassium and other 579 mineral contents of green, roasted and instant coffees. Journal of 580 the Science of Food Agriculture, 25, 1389-1404.

581 de Assuncao, L. S., da Luz, J. M. R., da Silva, M. C. S., Viera, P. 582 A. F., Bazzolli, D. M. S., Vanetti, M. C. D., \& Kasuya, M. C. M. 583 (2012). Enrichment of mushrooms: an interesting strategy for the 584 acquisition of lithium. Food Chemistry, 134, 1123-1127.

585 de Maria, C. A.B., Trugo, L. C., de Mariz e Miranda, L. S., \& 586 Salvador, E. (1998). Stability of 5-caffeoylquinic acid under 587 different conditions of heating. Food Research International, 31 , $588 \quad 6-7$.

589 Diaz, M. N., Frei, B., Vita, J. A., \& Keaney, J. F. Jr. (1997). 590 Antioxidants and atherosclerotic heart disease. New England 591 Journal of Medicine, 337, 408-416.

592 Esquivel, P., \& Jimenez, V. M. (2012). Functional properties of 593 coffee and coffee by-products. Food Research International, 46, $594 \quad 488-495$. 
595 Farah, A., de Paulis, T., Trugo, L. C., \& Martin, P. R. (2005).

596 Effect of roasting on the formation of chlorogenic acid lactones 597 in coffee. Journal of Agricultural and Food Chemistry, 53, $598 \quad 1505-1513$.

599 Farah, A., de Paulis, T., Moreira, D. P., Trugo, L. C., \& Martin, P. 600 R. (2006). Chlorogenic acids and lactones in regular and 601 water-decaffeinated arabica coffees. Journal of Agricultural and 602 Food Chemistry, 54, 374-381.

603 Food and Agricultural Organization. Food balance sheets $604 \quad[$ http://www.fao.org/].

605 Franca, A. S., Oliveira, L. S., Mendonca, J. C. F., \& Silva, X. A. 606 (2005). Physical and chemical attributes of defective crude and 607 roasted coffee beans. Food Chemistry, 90, 89-94.

608 Furusawa, M., Narita, Y., Iwai, K., Fukunaga, T., \& Nakagiri, O. 609 (2011). Inhibitory effect of a hot water extract of coffee 610 "silverskin" on hyaluronidase. Bioscience, Biotechnology, and 611 Biochemistry, 75, 1205-1207.

612 Gombert, A. K., Pinto, A. L., Castilho, L. R., \& Freire, D. M. G. 613 (1999). Lipase production by Penicillium restrictium in 614 solid-state fermentation using babassu oil cake as substrate. 615 Process Biochemistry, 35, 85-90.

616 Grembecka, M., Malinowska, E., \& Szefer, P. (2007). 617 Differentiation of market coffee and its infusions in view of their 618 mineral composition. Science of the Total Environment, 383, $61959-69$.

620 Harris, P. J., \& Smith, B. G. (2006). Plant cell walls and 621 cell-wall polysaccharides: structures, properties and uses in food 622 products. International Journal of Food Science and Technology, 
623

624 Hayashi, N., Iida, T., Yamada, T., Okuma, K., Takehara, I., 625 Yamamoto, T., Yamada, K., \& Tokuda, M. (2010). Study on the 626 postprandial blood glucose suppression effect of D-psicose in 627 borderline diabetes and the safety of long-term ingestion by 628 normal human subjects. Bioscience, Biotechnology, and 629 Biochemistry, 74, 510-519.

630 Imai, K., Kishimoto, N., Kakino, Y., Mochida, K., \& Fujita, T. 631 (2004). In vitro antioxidative effects and tyrosinase inhibitory 632 activities of seven hydroxycinnamoyl derivatives in green coffee 633 beans. Journal of Agricultural and Food Chemistry, 52, $634 \quad 4893-4898$.

635 Iwai, K., Narita, Y., Fukunaga, T., Nakagiri, O., Kamiya, T., 636 Ikeguchi, M., \& Kikuchi, Y. (2012). Study on the postprandial 637 glucose responses to a chlorogenic acid-rich extract of 638 decaffeinated green coffee beans in rats and healthy human 639 subjects. Food Science and Technology Research, 18, 849-860.

640 Kakegawa, H., Matsumoto, H., \& Satoh, T. (1992). Inhibitory 641 effects of some natural products on the activation of 642 hyaluronidase and their antiallergic actions. Chemical and 643 Pharmaceutical Bulletin, 40, 1439-1442.

644 Kataoka, M., Wiboonsirikul, J., Kimura, Y., \& Adachi, S. (2008). 645 Properties of extracts from wheat bran by subcritical water 646 treatment. Food Science and Technology Research, 14, 553-556. 647 Khajavi, S. H., Kimura, Y., Oomori, T., Matsuno, R., \& Adachi, S. 648 (2005). Degradation kinetics of monosaccharides in subcritical 649 water. Journal of Food Engineering, 68, 309-313.

650 Knopp, S., Bytof, G., \& Selmar, D. (2006). Influence of 
651 processing on the content of sugars in green Arabica coffee beans.

652 European Food Research and Technology, 223, 195-201.

653 Kondamudi, N., Mohapatra, S. K., \& Misra, M. (2008). Spent

654 coffee grounds as a versatile source of green energy. Journal of 655 Agricultural and Food Chemistry, 56, 11757-11760.

656 Ky, C.-L., Louarn, J., Dussert, S., Guyot, B., Hamon, S., \& 657 Noirot, M. (2001). Caffeine, trigonelline, chlorogenic acids and 658 sucrose diversity in wild Coffea arabica L. and C. canephora P. 659 accessions. Food Chemistry, 75, 223-230.

660 Lambert, J. D., \& Yang, C. S. (2003). Mechanisms of cancer 661 prevention by tea constituents. Journal of Nutrition, 133 , $6623262 \mathrm{~S}-3267 \mathrm{~S}$.

663 Lang, A. E., \& Lozano, A.M. (1998). Parkinson's disease. First 664 of two parts. New England Journal of Medicine, 339, 1044-1053. 665 Lang, R., Fromme, T., Beusch, A., Wahi, A., Klingenspor, M., \& 666 Hofmann, T. (2013).

$6672-O-\beta-\mathrm{D}-\mathrm{Glucopyranosyl-carboxyatractyligenin} \mathrm{from} \mathrm{Coffea} \mathrm{L.}$ 668 inhibits adenine nucleotide translocase in isolated mitochondria 669 but is quantitatively degraded during coffee roasting. 670 Phytochemistry, 93, 124-135.

671 Lashermes, P., Andrade, A. C., \& Etienne, H. (2008). Genomics 672 of coffee, one of the world's largest traded commodities. In P. H. 673 Moore, \& R. Ming (Eds.), Genomics of tropical crop plants (pp. 674 203-225). New York: Springer.

675 Lecumberri, E., Mateos, R., Izquierdo-Pulido, M., Ruperez, P., 676 Goya, L., \& Bravo, L. (2007). Dietary fibre composition, 677 antioxidant capacity and physico-chemical properties of a 678 fibre-rich product from cocoa (Theobroma cacao L.) Food 
Chemistry, 104,948-954.

680 Machado, E. M. S., Rodriguez-Jasso, R. M., Teixeira, J. A., \& 681 Mussatto, S. I. (2012). Growth of fungal strains on coffee 682 industry residues with removal of polyphenolic compounds. 683 Biochemical Engineering Journal, 60, 87-90.

684 Miller, D. J. \& Hawthorne, S. B. (1998). Method for determining 685 the solubilities of hydrophobic organics in subcritical water. 686 Analytical Chemistry, 70, 1618-1621.

687 Montonen, J., Knekt, P., Jarvinen, R., Aromaa, A., \& Reunanen, 688 A. (2003). Whole-grain and fiber intake and the incidence of 689 type 2 diabetes. The American Journal of Clinical Nutrition, 77, $690 \quad 622-629$.

691 Murthy, P. S., Naidu, M. M., \& Srinivas, P. (2009). Production of $692 \alpha$-amylase under solid-state fermentation utilizing coffee waste.

693 Journal of Chemical Technology and Biotechnology, 84, $6941246-1249$.

695 Murthy, P. S., \& Naidu, M. M. (2012). Sustainable management 696 of coffee industry by-products and value addition-a review. 697 Resources, Conservation and Recycling, 66, 45-58.

698 Mussatto, S. I. \& Teixeira, J. A. (2010). Increase in the 699 fructooligosaccharides yield and productively by solid-state 700 fermentation with Aspergillus japonicus using agro-industrial 701 residues as support and nutrient source. Biochemical 702 Engineering Journal, 53, 154-157.

703 Mussatto, S. I., Carneiro, L. M., Silva, J. P. A., Roberto, I. C., \& 704 Teixeira, J. A. (2011). A study on chemical constituents and 705 sugars extraction from spent coffee grounds. Carbohydrate 706 Polymers, 83, 368-374. 
707 Mussatto, S. I., Machado, E. M. S., Martins, S., \& Teixeira, J. A. 708 (2011). Production, composition, and application of coffee and 709 its industrial residues. Food Bioprocess Technology, 4, 661-672. 710 Mussatto, S. I., Machado,E. M. S., Carneiro, L. M., \& Teixeira, 711 J. A. (2012). Sugars metabolism and ethanol production by 712 different yeast strains from coffee industry wastes hydrolysates. 713 Applied Energy, 92, 763-768.

714 Napolitano, A., Lanzuise, S., Ruocco, M., Arlotti, G., Ranieri, R., 715 Knutsen, S. H., Lorito, M., \& Fogliano, V. (2006). Treatment of 716 cereal products with a tailored preparation of Trichoderma 717 enzymes increases the amount of soluble dietary fiber. Journal of 718 Agricultural and Food Chemistry, 54, 7863-7869.

719 Napolitano, A., Fogliano, V., Tafuri, A., \& Ritieni, A. (2007). 720 Natural occurrence of ochratoxin A and antioxidant activities of 721 green and roasted coffees and corresponding byproducts. Journal 722 of Agricultural and Food Chemistry, 55, 10499-10504.

723 Narita, Y., \& Inouye, K. (2009). Kinetic analysis and mechanism 724 on the inhibition of chlorogenic acid and its components against 725 porcine pancreas $\alpha$-amylase isozymes I and II. Journal of 726 Agricultural and Food Chemistry, 57, 9218-9225.

727 Narita, Y., \& Inouye, K. (2011). Inhibitory effects of chlorogenic 728 acids from green coffee beans and cinnamate derivatives on the 729 activity of porcine pancreas $\alpha$-amylase isozyme I. Food 730 Chemistry, 127, 1532-1539.

731 Narita, Y., \& Inouye, K. (2012). High antioxidant activity of 732 coffee silverskin extracts obtained by the treatment of coffee 733 silverskin with subcritical water. Food Chemistry, 135, 943-949. 734 Narita, Y., Iwai, K., Fukunaga, T., \& Nakagiri, O. (2012). 
735 Inhibitory activity of chlorogenic acids in decaffeinated green 736 coffee beans against porcine pancreas lipase and effect of a 737 decaffeinated green coffee bean extract on an emulsion of olive 738 oil. Bioscience, Biotechnology, and Biochemistry, 76, $739 \quad 2329-2331$.

740 Narita, Y., \& Inouye, K. (2013). Degradation kinetics of 741 chlorogenic acid at various $\mathrm{pH}$ values and effects of ascorbic 742 acid and epigallocatechin gallate on its stability under alkaline 743 conditions. Journal of Agricultural and Food Chemistry, 61, $744966-972$.

745 Oliveira, L. S., Franca, A. S., Mendonca, J. C. F., \& 746 Barros-Junior, M. C. (2006). Proximate composition and fatty 747 acids profile of green and roasted defective coffee beans. 748 LWT-Food Science and Technology, 39, 235-239.

749 Orrhage, K., Sjostedt, S., \& Nord, C. E. (2000). Effect of 750 supplements with lactic acid bacteria and oligofructose on the 751 intestinal microflora during administration of cefpodoxime 752 proxetil. Journal of Antimicrobial Chemotherapy, 46, 603-611.

753 Park, E. Y., Morimae, M., Matsumura, Y., Nakamura, Y., \& Sato, 754 K. (2008). Antioxidant activity of some protein hydrolysates and 755 their fractions with different isoelectric points. Journal of 756 Agricultural and Food Chemistry, 56, 9246-9251.

757 Pourfarzad, A., Mahdavian-Mehr, H., \& Sedaghat, N. (2013).

758 Coffee silverskin as a source of dietary fiber in bread-making: 759 optimization of chemical treatment using response surface 760 methodology. LWT-Food Science and Technology, 50, 599-7606. 761 Rodriguez, R., Jimenez, A., Bolanos, J. F., Guillen., R, \& 762 Heredia, A. (2006). Dietary fibre from vegetable products as 
source of functional ingredients. Trends in Food Science \&

764 Technology, 17, 3-15.

765 Rodriguez Couto, S., \& Sanroman, M. A. (2005). Application of 766 solid-state fermentation to ligninolytic enzyme production. 767 Biochemical Engineering Journal, 22, 211-219.

768 Rodriguez Couto, S., \& Sanroman, M. A. (2006). Application of 769 solid-state fermentation to food industry-A review. Journal of 770 Food Engineering, 76, 291-302.

771 Rufford, T. E., Hulicova-Jurcakova, D., Zhu, Z., \& Lu, G. Q. 772 (2008). Nanoporous carbon electrode from waste coffee beans for 773 high performance supercapacitors. Electrochemistry 774 Communications, 10, 1594-1597.

775 Saenger, M., Hartge, E.-U., Werther, J., Ogada, T., \& Siagi, Z. 776 (2001). Combustion of coffee husks. Renewable Energy, 23, $777 \quad 103-121$.

778 Saura-Calixto, F., Garcia-Alonso, A., Goni, I., \& Bravo, L. 779 (2000). In vitro determination of the indigestible fraction in 780 foods: an alternative to dietary fiber analysis. Journal of 781 Agricultural and Food Chemistry, 48, 3342-3347.

782 Sereewatthanawut, I., Prapintip, S., Watchiraruji, K., Goto, M., 783 Sasaki, M., \& Shotipruk, A. (2008). Extraction of protein and 784 amino acids from deoiled rice bran by subcritical water 785 hydrolysis. Bioresource Technology, 99, 555-561.

786 Somporn, C., Kamtuo, A., Theerakulpisut, P., \& Siriamornpun, S. 787 (2011). Effects of roasting degree on radical scavenging activity, 788 phenolics and volatile compounds of Arabica coffee beans 789 (Coffea arabica L. cv. Catimor). International Journals of Food 790 Science \& Technology, 46, 2287-2296. 
791 Southgate, D. A. T. (1978). Dietary fiber: analysis and food 792 sources. The American Journal of Clinical Nutrition, 31 , 793 S $107-$ S 110.

794 Takayanagi, R., Inoguchi, T., \& Ohnaka, K. (2011). Clinical and 795 experimental evidence for oxidative stress as an exacerbating 796 factor of diabetes mellitus. Journal of Clinical Biochemistry and $797 \quad$ Nutrition, 48, 72-77.

798 Tawfik, M. S., \& El Bader, N. A. (2005). Chemical 799 characterization of harar and berry coffee beans with special 800 reference to roasting effect. Journal of Food Technology, 3 , $801 \quad 601-604$.

802 United States Department of Agriculture. Coffee: World Markets 803 and Trade [http://www.usda.gov/wps/portal/usda/usdahome].

804 Usuki, C., Kimura, Y., \& Adachi, S. (2008). Degradation of 805 pentaoses and hexouronic acids in subcritical water. Chemical 806 Engineering and Technology, 31, 133-137.

807 van Boxtel, J., Berthouly, M., Carasco, C., Dufour, M., \& Eskes, 808 A. (1995). Transient expression of b-glucuronidase following 809 biolistic delivery of foreign DNA into coffee tissues. Plant Cell 810 Reports, 14, 748-752.

811 van de Laar, F. A., Lucassen, P. L., Akkermans, R. P., van de

812 Lisdonk, E. H., Rutten, G. E., \& van Weel, C. (2005). $813 \alpha$-Glucosidase inhibitors for patients with type 2 diabetes. 814 Diabetes Care, 28, 154-163.

815 Vieira, H. D. (2008). Coffee: The plant and its cultivation. In M. 816 Souza (Ed.), Plant-parasitic nematodes of coffee (pp. 3-18). 817 Dordrecht: Springer.

818 Wakita, Y., Harada, O., Kuwata, M., Fujimura, T., Yamada, T., 
819 Suzuki, M., \& Tsuji, K. (2004). Preparation of subcritical 820 water-treated okara and its effect on blood pressure in 821 spontaneously hypertensive rats. Food Science and Technology 822 Research, 10, 164-167.

823 Wiboonsirikul, J., Kimura, Y., Kadota, M., Morita, H., Tsuno, T., $824 \&$ Adachi, S. (2007). Properties of extracts from defatted rice 825 bran by its subcritical water treatment. Journal of Agricultural 826 and Food Chemistry, 55, 8759-8765.

827 Wu, X., Beecher, G. R., Holden, J. M., Haytowitz, D. B., 828 Gebhardt, S. E., \& Prior, R. L. (2004). Lipophilic and 829 hydrophilic antioxidant capacities of common foods in the 830 United States. Journal of Agricultural and Food Chemistry, 52, $8314026-4037$.

832 


\section{Figure captions}

834

835 Figure 1. Typical section of a coffee cherry

836

837

838

839

840

841

842

843

844

845

846

847

848

849

850

851

852

853

854

Green coffee beans

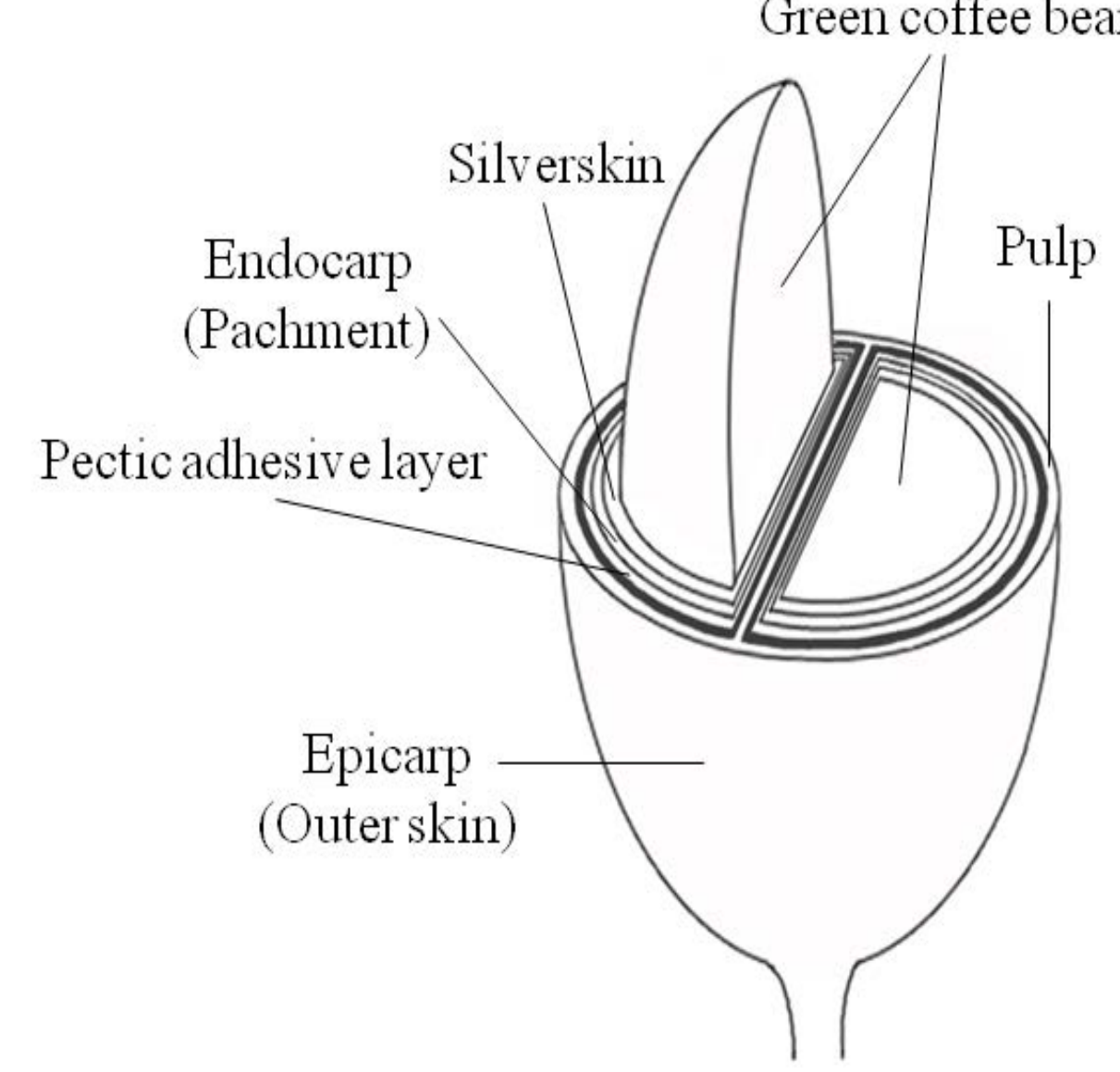

855

856

857

858

859

860 
Table 1. Coffee silverskin nutritional composition (g per $100 \mathrm{~g}$ )

862

863

864

865

\begin{tabular}{|c|c|c|c|c|c|}
\hline \multirow{2}{*}{ Component } & \multicolumn{5}{|c|}{$\mathrm{CS}$} \\
\hline & - & from Arabica & from Canephora & from Arabica & - \\
\hline Proteins & $18.6 \pm 0.6$ & $18.6 \pm 0.3$ & $17.9-19.0$ & $18.4-19.0$ & 16.2 \\
\hline Fats & $2.2 \pm 0.1$ & $2.2 \pm 0.5$ & $2.50-2.92$ & $1.56-3.28$ & N. A. \\
\hline Carbohydrates & $62.1 \pm 1.6$ & $65.1 \pm 1.2$ & $47.0-80.5$ & $34.6-52.0$ & N. A. \\
\hline Reducing sugars & $0.2 \pm 0.01$ & N. A. & N. D. ${ }^{b}$ & N. D. & N. A. \\
\hline Moisture & $7.3 \pm 0.4$ & $7.1 \pm 0.2$ & N. A. & N. A. & 4.7 \\
\hline Ashes & $7.0 \pm 0.2$ & $7.0 \pm 0.2$ & N. A. & N. A. & N. A. \\
\hline Caffeine & N. $A^{a}$ & N. A. & $0.81-1.37$ & $0.83-1.16$ & N. A. \\
\hline Ochratoxin A & $4<$ & N. A. & N. A. & N. A. & N. A. \\
\hline Total dietary fïber & $62.4 \pm 0.6$ & $62.4 \pm 0.5$ & $53.4-69.2$ & $56.4-65.9$ & N. A. \\
\hline Insoluble dietary fiber & $53.7 \pm 0.2$ & $53.7 \pm 0.4$ & $48.5-64.2$ & $50.1-60.7$ & N. A. \\
\hline Soluble dietary fiber & $8.8 \pm 0.4$ & $8.8 \pm 0.6$ & $4.9-9.3$ & $5.0-6.3$ & N. A. \\
\hline Glucan & N. A. & N. A. & N. A. & N. A. & 17.8 \\
\hline Xylan & N. A. & N. A. & N. A. & N. A. & 4.7 \\
\hline Arabinan & N. A. & N. A. & N. A. & N. A. & 2.0 \\
\hline Galactan & N. A. & N. A. & N. A. & N. A. & 3.8 \\
\hline Mannan & N. A. & N. A. & N. A. & N. A. & 2.6 \\
\hline Lignin & N. A. & N. A. & N. A. & N. A. & 30.2 \\
\hline Acetyl groups & N. A. & N. A. & N. A. & N. A. & 3.0 \\
\hline Extractives & N. A. & N. A. & N. A. & N. A. & 15.0 \\
\hline References & $\mathrm{A}$ & $\mathrm{B}$ & $\mathrm{C}$ & $\mathrm{C}$ & $\mathrm{D}$ \\
\hline
\end{tabular}

873

874

875 from Borrelli et al. (2004) and Napolitano et al. (2006) (A),

876 Pourfarzad et al. (2013) (B), Napolitano et al. (2007) (C), and

877 Mussatto et al. (2012) (D).

$878{ }^{a}$ Not analyzed

$87 a^{b}$ Not detected

880 
881 Table 2. Yields of soluble solid from CS of solid and each 882 component and antioxidant activity of CS water extraction ${ }^{a}$

\begin{tabular}{|c|c|c|c|c|c|c|c|c|}
\hline 884 & $\begin{array}{c}\text { Extraction } \\
\text { Temperature } \\
\left({ }^{\circ} \mathrm{C}\right)\end{array}$ & $\begin{array}{c}\text { Yields of } \\
\text { soluble solid } \\
(\mathrm{g} / 100 \mathrm{~g})\end{array}$ & $\begin{array}{l}\text { Proteins } \\
(\mathrm{g} / 100 \mathrm{~g})\end{array}$ & $\begin{array}{l}\text { Carbohydrates } \\
(\mathrm{g} / 100 \mathrm{~g})\end{array}$ & $\begin{array}{l}\text { Caffeine } \\
(\mathrm{g} / 100 \mathrm{~g})\end{array}$ & $\begin{array}{l}\text { Total phenolics } \\
(\mathrm{g} / 100 \mathrm{~g})\end{array}$ & $\begin{array}{c}\text { H-ORAC } \\
(\mu \mathrm{mol} \mathrm{TE} / \mathrm{g} \text { of CS extracts) }\end{array}$ & $\begin{array}{c}\text { DPPH } \\
(\mu \mathrm{mol} \mathrm{TE} / \mathrm{g} \text { of CS extracts) }\end{array}$ \\
\hline \multirow{3}{*}{885} & 25 & $16 \pm 1$ & $21.2 \pm 1.8$ & $36.6 \pm 2.1$ & $2.6 \pm 0.0$ & $3.6 \pm 0.3$ & $354 \pm 44$ & $74 \pm 13$ \\
\hline & 80 & $19 \pm 1$ & $23.6 \pm 1.2$ & $40.5 \pm 3.0$ & $2.3 \pm 0.0$ & $3.5 \pm 0.1$ & $384 \pm 58$ & $75 \pm 18$ \\
\hline & 180 & $25 \pm 1$ & $37.8 \pm 2.0$ & $47.7 \pm 2.9$ & $1.6 \pm 0.0$ & $8.5 \pm 0.5$ & $1223 \pm 65$ & $184 \pm 28$ \\
\hline \multirow{3}{*}{886} & 210 & $29 \pm 1$ & $53.5 \pm 1.4$ & $22.8 \pm 5.0$ & $1.4 \pm 0.0$ & $12.4 \pm 0.9$ & $2321 \pm 169$ & $323 \pm 39$ \\
\hline & 240 & $27 \pm 1$ & $58.2 \pm 1.0$ & $8.6 \pm 1.0$ & $1.6 \pm 0.0$ & $13.0 \pm 0.6$ & $2611 \pm 150$ & $371 \pm 33$ \\
\hline & 270 & $23 \pm 1$ & $54.4 \pm 1.1$ & $7.1 \pm 0.6$ & $1.8 \pm 0.0$ & $12.3 \pm 0.9$ & $2629 \pm 193$ & $379 \pm 36$ \\
\hline
\end{tabular}

887

$88 a^{a}$ from Narita \& Inouye (2012).

889 
890 Table 3. Yields of each component obtained from CS of solid 891 by water extraction ${ }^{a}$

892

893

894

895

896

\begin{tabular}{ccccccc}
\hline $\begin{array}{c}\text { Extraction } \\
\begin{array}{c}\text { Temperature } \\
\left({ }^{\circ} \mathrm{C}\right)\end{array}\end{array}$ & $\begin{array}{c}\text { Proteins } \\
(\mathrm{g} / 100 \mathrm{~g})\end{array}$ & $\begin{array}{c}\text { Carbohydrates } \\
(\mathrm{g} / 100 \mathrm{~g})\end{array}$ & $\begin{array}{c}\text { Caffeine } \\
(\mathrm{g} / 100 \mathrm{~g})\end{array}$ & $\begin{array}{c}\text { Total phenolics } \\
(\mathrm{g} / 100 \mathrm{~g})\end{array}$ \\
\hline 25 & 3.3 & \pm 0.2 & 5.7 & \pm 0.2 & $0.4 \pm 0.0$ & $0.6 \pm 0.0$ \\
80 & 4.5 & \pm 0.3 & $7.7 \pm 0.9$ & $0.4 \pm 0.0$ & $0.7 \pm 0.0$ \\
180 & 9.5 & \pm 5.0 & $12.1 \pm 0.9$ & $0.4 \pm 0.0$ & $2.2 \pm 0.1$ \\
210 & 15.7 & \pm 0.4 & $6.7 \pm 0.3$ & $0.4 \pm 0.0$ & $3.6 \pm 0.3$ \\
240 & 15.5 & \pm 0.7 & $2.3 \pm 0.1$ & $0.4 \pm 0.0$ & $3.5 \pm 0.2$ \\
270 & 12.5 & \pm 0.4 & $1.6 \pm 0.1$ & $0.4 \pm 0.0$ & $2.8 \pm 0.1$ \\
\hline
\end{tabular}

897

898

$1.6 \pm 0.1$

$2.8 \pm 0.1$

899

$900{ }^{a}$ from Narita \& Inouye (2012).

901

902 
903

904

905

906

907

908

909

910

911

912

913

914

915

916

917

918

919

920

921

922

923

$924 \quad$ Figure 1 